\title{
MEDIA BIAS AND THE ROLE OF INTERNET-USER- GENERATED CONTENT IN CRISIS MANAGEMENT: A CASE-STUDY ABOUT THE COMMUNICATION OF THE HUNGARIAN POLICE FORCE AFTER THE 2016 BUDAPEST EXPLOSION
}

\author{
DÁNIEL GERGö PINTÉR ${ }^{l}$
}

\begin{abstract}
The 2016 Budapest explosion occurred on September 24, 2016 when a young man detonated a nail bomb in an attempt to kill two patrolling police officers. This case-study analyses the official communication of the Hungarian police force, focusing on the time that elapsed until their first official reaction. I argue that the first twenty-four hours after the explosion were the most crucial, and that working with speed and efficiency is important. I claim that a successful crisis management process takes not only the bias of mass media into consideration, but also the influence of internet-user-generated content and conspiracy theories as well. The publication of a holding statement, designed to help control the message the public will hear immediately following an incident, is also essential.
\end{abstract}

KEYWORDS: crisis communication, bombing, information society, public relations, management, holding statement

\footnotetext{
1 Dániel Gergő Pintér is the Head of Corporate Communications of MTA SZTAKI (HAS, Institute for Computer Science and Control), is lecturer at the BME (Budapest University of Technology and Economics), part-time lecturer at BMU (Budapest Metropolitan University), and Chief Strategy Officer at Media 2.0 Communications Ltd. He studies at the PhD. Program of the BME Doctoral School of Philosophy and History of Science. The research leading to the findings described in this paper was supported by OTKA/NKFIH grant No. K-109456 "Integrated reasoning".The author is indebted to István Danka, János Tanács and two anonymous reviewers for their valuable critical remarks upon the first version of the present paper. E-mail: pinter.daniel.gergo@gmail.com
} 


\section{THE LITERATURE ABOUT INSTITUTIONAL APOLOGIES}

The word "crisis" is derived from the Greek word kpílৎ ("krizei"); its meaning is decision, resolution or turn. In English the term can be defined as a critical state, hardship or a hazardous situation occurring in the life of a person or a group, and as such one accompanied by operational problems and conflicts (Bundy et al. 2016: 2). The word is often used as synonym of "distress", since both concepts involve a feeling of being tense, threatened, hopeless and lost (Coombs 2010b: 19), which not only significantly affects the troubleshooting capacity of those involved, but also suggests the possibility of a turn in a negative or positive direction (Tanács - Zemplén 2015: 2). In the present study following the traditions of the international management literature - I consider these two expressions to be equivalent in meaning; accordingly, from now on I use the words "distress" and "crisis" synonymously.

The most notable professions that deal with the features of different crises, like management, communications, and psychology, identify four primary characteristics of the concept. Bundy et al. (2016) analyzed published studies in international management journals about crisis. Despite the diversity of the different scientific perspectives and the multiplicity of intellectual traditions, the following general features were attributed to crises:

1. They induce uncertainty and disturbance, and spur requests to change the former management or communication practices (Kahn et al. 2013).

2. They endanger the image, reputation and public relations of organizations (Pintér 2016b: 36; Kahn et al. 2013).

3. As a definitive part of a longer, complex process, crises attract great public interest (Jacques et al. 2009; Roux-Dufort 2007).

4. They are closely related to individual or group behavior, thus they can be considered socially constructed phenomena and may be subjectively interpreted in numerous ways (Coombs 2010b: 478).

The profession and the scientific community interpret crises as events that stand out from everyday routine, as mainly unforeseen, and as potentially endangering the implementation of objectives (Seeger et al. 1998: 233). Such 'demolishing' phenomena also bring recognition that former processes are no longer sustainable under the current circumstances (Venette 2003: 43), thus the zero point in the successful management of a hazardous situation is actually " $a$ decision made with the aim of reaching a turn[ing point,] accompanied by setting up [alternatives], their management and communication" (Pintér 2016b: 36). 


\section{GOALS OF THE CASE-STUDY: AN EXAMINATION OF THE SCIENTIFIC, SOCIAL AND PROFESSIONAL RELEVANCE OF THE BUDAPEST EXPLOSION}

This study examines the communication of the Hungarian police related to the Budapest explosion considering crisis management protocols and PR. Several professional and other social factors explain why this case is worth scientific analysis, which I separately discuss below:

1. The professional relevance of the Budapest explosion is clearly indicated by the Annual Crisis Report of Hungary 2016, which contains all the Hungarian related distresses - 460 in number -, ranking the Budapest explosion as a top priority case (Böhm et al. 2017). This is for two main reasons: first of all, the explosion is considered a "hard crisis" (Nyárádi - Szeles 1999: 288), because it was a threat to human life: a suddenly occurring event with a powerful effect which required the highest level of sensitivity and preparedness; on the other hand, because of the rare combination of the circumstances of the crime - its location, method, time and target - the case received wide interest, it thematized mainstream media for months, and generated a lot of media attention and appearances. The experts in the field collected their thoughts in the columns of numerous Hungarian journals and at national conferences; nevertheless, a critical scientific description of the case in English has not been published yet.

The relevance of this article is also proved by the fact that it is not only provides professional and practical points of reference to police forces who meet with crises every day, but it also presents general theoretical methodological suggestions for the whole crisis management profession; it accomplishes this from a new perspective, by approaching the topic from the perspective of content and conspiracy theories generated by internet users.

Ensuing from the significant number of media appearances related to the Budapest explosion, a substantial amount of source material was available for analysis which reduced the chance of subjectivity in the writing of the recommendations and supported the objective, scientific perspective employed in this analysis.

2. The social importance of the Budapest explosion is confirmed (in addition to its major public interest) by its proximity to the date of a referendum about 'migrant quotas' and other political-public-life juxtapositions. A referendum was held on October 2, 2016 in which Hungarian citizens with the right to vote could voice their opinion about whether the European Union should prescribe the obligatory settlement of persons other than Hungarian citizens 
in Hungary without the approval of parliament. The related referendum was initiated by the government in connection with the European migration crisis. The referendum was invalid, since less than half of those who had the right to vote actually did so, although $98 \%$ of those whose votes were valid rejected the proposition (valasztas.hu 2016). The intensive campaign period prior to the referendum provides a definitive context for the crisis analyzed in this case study in two areas; on the one hand, only ten days elapsed between the bomb explosion and the referendum, while on the other hand, the explosion raised public security issues similar to those voted on in the referendum. Since the identity of the perpetrator was unknown for a long time, and an anti-migration public mood was constructed over the period of political campaigning, the explosion - due to the supposition that an unknown immigrant was the perpetrator - could have significantly impacted the rate of participation and thus the result of the referendum. In 2016 in Hungary, anything that could have been associated with terrorism or the issue of migration was also a campaign topic, not only an affair of internal security (Pintér 2016c).

The present script approaches the case study from a crisis communication perspective, thus the announcements of those involved are not analyzed from a political communication perspective. In spite of this, the analysis deals with the public aspects of the explosion which created rich soil for conspiracy theories in connection with the crisis situation, and content generated by internet users.

Emphasis is put on the time that elapsed before the first official response to the explosion and to the importance of the so-called temporary declaration, which not only prevented the widening of the scope of problems associated with the crisis situation, but created a public point of alignment until other valuable information was published (Anthonissen 2009: 71-72). I argue that hard crises (i.e. situations representing serious hazard that occur suddenly and which are hard to manage (Nyárádi - Szeles 1999: 288)) and delays in announcing the official standpoint can cause an information deficit and thus cause interestowners to turn towards other less authentic sources of information.

My central claim is that successful crisis communication practice calculates equally with 1 . distortions of the media, and 2. the communication of private persons that are articulated in mass media (i.e. with content generated by internet users and with potential conspiracy theories) in addition to the declarations of any competent experts, since such content - through the intermediation of social media - can influence crowds.

I attempt to prove this claim through use of secondary literature research, an analysis of media sources selected according to their circulation, and an 
evaluation of online voting. Admittedly, my theses are derived from a review of subjectively selected media sources rather than a systematic media analysis. The online press products analyzed in the following sections, and the results of voting on two fora and one blog can be considered a representative survey and only partially primary quantitative research; however, they provide an appropriate illustration of the distribution of opinions related to the explosion and their trends due to the mass access and great number of comments on the analyzed surfaces. A systematic media analysis and a representative survey would certainly provide further evidence for (dis)confirming the claims of this paper. In such an analysis, investigation of the responses of the non-internetusing segment of the public (e.g. incorporating a classification of their initial perceptions about the explosion) could be important additions.

A further limitation is that the background literature and practical operation of the information shared on Web 2.0 surfaces are not discussed in detail. A discussion of what the difference is between crisis communication and crisis management at the official organs responsible for public tasks and in brands with business goals would also be worth a separate article. A case study such as the former could describe best and worst practices and other domestic and international cases that have occurred in the past few years in the light of current media circumstances.

In the following section I describe the most important circumstances of the explosion, conceptualize the crisis event as the focus of the case study, and briefly describe the tools of the two disciplinary areas. In the second part of the study, I examine the phenomena typical of the twenty-four hours directly following the explosion, and then analyze in detailed how the former made the crisis more intensive and the communication space - which the authorities hoped to dominate - more complex.

\section{EXPLOSION, COMMUNICATION AND MANAGEMENT}

On September 24, 2016 an explosion took place at the entrance to an empty shop being prepared for reconstruction on Teréz körút in the downtown area of Budapest, the capital of Hungary (Joób 2016a). Three people were injured: a policewoman on a pedestrian patrol was critically wounded, and her partner was seriously injured (hvg.hu 2016). The Catastrophe Protection Directorate of the Capital closed down the area for the period of the investigation and public transport was rerouted (Privátbankár 2016). Entrance to the area was 
permitted to residents only, and such residents were identified and questioned. Though it is an unquestionable fact that the authorities immediately commenced investigating the crime scene, they waited almost twenty hours before issuing any centralized information, and the images of the alleged perpetrator taken by the space monitoring cameras were published only forty-one hours later (Joób et al. 2016).

The alleged perpetrator, who, based on data from the investigation, carried out the explosion alone, was detained after a nearly one-month-long investigation by employees of the Terror Prevention Centre on October 19, 2016 (hirado.hu 2016). However, the reason for the criminal act is unknown till this day (Német 2017), although in the critical period following the explosion several alternatives were put forward regarding the motivation of the perpetrator. Before discussing why it is problematic that the authorities did not keep speculation related to the motive for the bombing under control - allowing speculation of a wide range, extending from terror attack to mysterious political intrigue -, I classify the events below.

Due to the broad interpretation of the concept, hazardous situations can be interpreted on different levels. Different crisis situations can be classified into more homogenous groups according to the scope of those involved, the reason(s) for the crisis, characteristics, severity and manageability (Nyárádi - Szeles 1999: 284-289). This study examines events from the standpoint of the Hungarian authorities for two reasons: first, because it was policemen who fell victim to the explosion in Budapest, and second, because of the nature of the response, which was accompanied by the intervention of the police (Perlaky-Papp 2016).

As pointed out in the Annual Crisis Report of Hungary (Böhm et al. 2017), from the standpoint of authorities, the explosion at Teréz körút can be classified as one of critical distress, since the shop was severely damaged and personal injury also occurred. For those involved it can be considered an incidence of local distress, since its consequences mainly impacted the residents of the capital. As for the origin and cause of the act of aggression, human malignancy occurred. From the perspective of the organization that sustained the state of crisis, the event is considered an external crisis, since the explosion did not relate directly to the inner life of the police, or to any mismanegement of theirs, but due to the basic function of this organization they were obliged to handle the crisis that followed the explosion. Regarding the manageability of the crisis, we claim that a hard crisis occurred: the explosion was an event with 'hard' impacts involving serious hazard, it was unpredicted, and its consequences were hard to handle. As for duration, it was a fast course crisis: the perpetrator was detained within one month of the explosion (Dull 2016). However, the Hungarian police forces are still engaged with the case, keeping the topic on the agenda of the 
daily media to this day. In this regard, it can be classified as long-continued, socalled publicistic crisis (Böhm et al. 2017).

Before discussing point by point how delays in official information made the crisis situation more complex and how they expanded the communication space required to be handled by the police in the critical period following the explosion, I clarify that the tools of the professions appearing in this analysis are twofold: 1. those of communication, and 2. those of management.

1. Crisis communication is a sub-discipline of the Public Relations profession. Besides loss mitigation and the reestablishment of security, it is an important aim of information transmission in hazardous situations to successfully protect the images previously defined by the PR tools of the organization or entity being reputationally endangered (Pintér 2016b: 37). In this process, the scheduling and quality of interactions, a responsible crisis-reaction approach, and selected messages aligned with the interests of stakeholders are of key importance (Coombs 2007). The tools of communication primarily assist in the proactive interpretation and identification of the crisis event and the roles of those involved (Pintér 2016a: 41).

2 . The aim of crisis management is to coordinate optimizing activities in order to facilitate a return to normal activity (Groh 2014). The arrangement and harmonization of different financial and human resources are within the scope of the tools of the profession, and the aims of an endangered organization are to successfully and efficiently raise productivity and rebuild confidence with interest-owners (Bundy et al. 2016). In addition, crisis managers often deal with organizational aspects of communication, and the selection of the circumstances of the reaction (Pintér 2016b: 39).

In the following sections I give a detailed presentation of the fact that Papp Károly, National Police Superintendent, and Keresztes Imre, Head of the Central Investigating Prosecution Office organized a press conference only twenty hours after the explosion (Joób 2016b), and until then no official information was made publically available. This escalated the crisis, introducing further communication challenges.

\section{THESIS OF THE STUDY, AND THE PHENOMENA ACCOMPANYING CRISES}

The emergence of information society has totally rearranged access to information (Beniger 1986). Information technology creates societal pressure 
for stimulation and news that has never been experienced before (Pintér 2016d: 676). The structure of the world has become network-based, and internet and online communication have emerged as a fate-defining experience (Castells 2006). The spread of new media and changes in news consumption habits raises the importance of the speed and suitability of the first reaction in crisis communication. If those involved - within a short time after the definition of the crisis situation - take steps and communicate with the purpose of reaching a turning point, they can seize the initiative and create the possibility of constructively shaping the crisis situation to their will (Anthonissen 2009). The lack of such a response can extend the basic scope of the problem, widening the scope of possible interpretations of the situation, this way escalating uncertainty and a feeling of emergency (for example, such as that created after the explosion). Accordingly, the press conference of the Hungarian police called on Sunday evening appears to be rather delayed; the fact that the organs of communication remained silent for twenty hours following the explosion was certainly counterproductive in respect of calming down residents and reinstating normal order (Perlaky-Papp 2016).

Failing to initiative an appropriate, effective and fast crisis response in the critical first twenty-four hours may have led to the appearance and strengthening of the following two phenomena:

1. Since due to their high news value crisis events significantly raise the interest of the media, in the period following the explosion the amount of erroneous and often speculatory news generally increased.

2. Due to the overly long time until the first formal announcement, besides reports from residents content and conspiracy theories generated by internet users also emerged and had to be taken into consideration.

In the following sections I discuss these two situations which had cumulative and mutual effects. Because the parties handling the situation following the explosion did not immediately curb the distorted media presentations and speculation spread by internet users, then at their first formal announcement they faced not only an increased amount of (and increasingly more complex) crisis interpretations, but more intense uncertainty from the public.

In the second part of this study, I rely on two types of source:

1. From the most frequently viewed and independent news portals on the domestic media market, I analyze those articles related to the explosion which temporarily took over the role of the authorities in respect of providing information, and by spreading partially unfounded information, quasi-strengthened speculation; 
2. I examine user content in the blogosphere, which - by preceding the official information announced by police - involved the fastest reactions to the explosion, and allowed reader commenting about the articles.

I classify the summarizing empirical content published on index.hu (Joób et al. 2016; Joób 2016c) in the former category; during the analysis of this material I primarily focus on specious - and regarding later knowledge, irrelevant or distorting - details, and on how editorial viewpoints can come to dominate the external and objective practices of crisis management (Anthonissen 2009). Items from the latter category include Konteóblog (which synthesized more than 400 comments), the Blblog (that has a voting system for comments) and the Frontember Megmondja blog (which is followed by several ten thousands of individuals); here I was primarily seeking to identify the most popular forms of speculation about the reason for the explosion among internet users.

Naturally, the results of the media analysis presented below, even if not universally valid, are valid in the situation created after the explosion in Budapest, since they reflect on the schemes appearing in the thinking of internet users who employed crisis publicity in the most significant way. The results of voting on online fora and blogs cannot be considered representative or primary quantitative research data that is scientifically interpretable, but they can be employed to properly illustrate (trends in) public opinion related to the bombing. Since the content generated by internet users, the different conspiracy theories, and the suppositions related to the causes of the bombing generated hundreds of thousands of views on some pages, along with several thousand social media 'shares' and a great number of comments within a couple of hours following the crisis, their power to influence the masses also must not be underestimated by crisis management and crisis communication professionals.

\section{ROLE OF THE MEDIA}

The media market of the twenty-first century features increasingly intensive news competition and a shortening news cycle (Zelizer 2009). Therefore, crises have become permanent topics in mainstream media. Due to the growth of online news portals and social surfaces, there have never been this many media competing for the attention of the target audience as today. However, this tendency has also accelerated the transformation of such media into the gutter press. "In the fight for readers only that one can stay on feet [sic], who is able to grab and keep the attention of people" (Bajomi 2009). The result of such an 
approach is a predominance of gutter-press-like reports about accidents, crimes, and scandals. The appearance of such topics in greater proportions has also somewhat transformed the style of the news: on an increasingly concentrated market, the goals of maximizing profit and customer demand for a variety of media often push dry facts into the background, elevating lurid, tabloidising conceptualizations to the foreground (Glynn 2000).

So-called Gresham's law is closely related to this phenomenon, and explains the media attention surrounding crises. This economic rule, recognized in the sixteenth century, says that bad money displaces good money. The example suggests that people unfailingly recognized coins with high gold content, and put them away as savings, while 'bad coins', of which kings had reduced the gold content, were used in payment. As a consequence, good coins practically disappeared from the market. According to some versions of the law adapted to the media market (Agnew 1969) and culture consumption (Bateson 1979), the press is more interested in negative than positive news (Nyárády - Szeles 1999: 116). Since crises often feature loud conflicts, and in extreme situations death, it is easy to understand why news about hazardous situations is over-represented in broadcasting.

The fact that crises are popular topics is also due to the fact that, in past years, the interest of the public has increasingly become more focused on the human dimension of news (Tanács - Zemplén 2015: 5), while in the case of crises, human agency also arises in respect of the issue of responsibility (i.e. who caused the hazardous situation, and in respect of involvedness, who fell victim to the situation). Resulting from changes in the demand for news consumption and the merger of the private and public sphere over the past decades, the personal, human stories of those involved are inevitably preferred by the gutter media, a fact that also promotes the place of crises in publicity (Zelizer 2009).

Representatives of organizations that are affected (threatened) should keep in mind that the media representation of crises can move general opinion in different directions. By raising interest, it may divert attention from other topics: it may increase sympathy, understanding, or positive attitudes, and it may eliminate suppositions and suspicions, but it can also strengthen negative feelings and trigger opposition (Nyárády - Szeles 1999: 295). In the age of infocommunication, the scope of effects of crises is hard to localize. Hence, due to the lack of the rapid provision of official information and a lack of identification of the problem, the public interpretation of a crisis event - via the intermediation of media - may be greatly distorted and intensively spread (Pintér 2016a).

The impact of the media also appears in the case of the Budapest explosion; delays in the official reaction only enhanced the uncontrollability of the crisis. Hungary's leading news portal, Index, attempted to explain the issues which 
the public was most interested in, with a pragmatic report including twelve significant points, practically taking over the role of authorities and strengthening speculation (Joób et al. 2016).

In the article, several lurid - and with hindsight, irrelevant - details were revealed, such as the fact that homeless people usually located at the site were not in front of the empty shop at the time of the explosion, thus it may be suspected that someone informed them in advance about the forthcoming events. Questions were also raised as to why no other people were injured at such a well-frequented place, how the authorities were able to mobilize several hundreds of professionals within a few minutes, and why there were several plain-clothes policemen in the area already (Joób et al. 2016).

An increasing number of reports also detailed how poorly the police patrols communicated with the frightened inhabitants who lacked information on the night of the explosion (Saturday night). The article mentioned a jihadist motivation for the explosion; it also reported that policemen asked witnesses several times if they had heard anyone shouting "Allah akbar!" (Joób et al. 2016). It also put forward the rumor that a political opponent had warned the government just before the explosion "not to simulate a terror attack and not to carry out any outrage" with the aim of increasing the number of voters that would take part in the referendum (atv.hu 2016).

If raising the idea of a mysterious political goal were not enough, the article also discussed several critiques related to the operation of the police, such as why they had kept silent for twenty hours, why they had not issued a sketch of the perpetrator, and why the pictures taken by the space monitoring cameras had not been published (Joób et al. 2016). The media crisis operation is well demonstrated by quotes from a well-known, eye-witness photo-reporter, whose statements (Joób 2016c) were distorted in several places. The interviewee himself requested correction, claiming that the style in which the editorials had communicated his words was nothing else than "luring [provocative], and as such [involved] the demolition of authenticity, bedeviling the already not too good public mood" (Joób 2016c).

The media representations presented in this section not only extended the scope of interpretations of the situation, but also escalated uncertainty and emergency following the explosion. Thus, besides reinstating public security, rectification of the distortions and ideas of the media and pacification of the public mood would have required the fastest possible official reaction by police (Anthonissen 2009). Since people are susceptible to believing the first story they hear (Nyárády - Szeles 1999: 295), reacting late is counter-productive. But before conceptualizing recommendations related to the lack of press releases about the explosion, in the next section I examine the impact of the second 
phenomenon: the impact of internet user-generated content and conspiracy theories on the management of the situation that occurred after the explosion.

\section{ROLE OF CONSPIRACY THEORIES AND INTERNET-USER-GENERATED CONTENT}

With the appearance of Web 2.0, in the past decade not only texts but image and video user-generated content (UCG) have become commonplace. The recent democratization of content generation implies that anyone can share their opinion with internet society, without restriction. As new technology and social media surfaces become more accessible and user-friendly, vast numbers of amateurs can interact with topics of interest without the presence of gatekeepers or content filtering (Pavlik 2014).

The appearance of UCG has a significant impact on crisis communication protocol (Anthonissen 2009), since in the age of media-convergence those involved in a crisis have an opportunity to fill the information gap - that occurs due to delays in official information - from other unofficial sources (Anthonissen 2009). During the hours that passed following the Budapest explosion until police engaged in communication, residents collected information from several other 'inauthentic' sources such as private blogs. The content of these included not only judgements of the work of the police, but also details about circumstances which increased the difficulty of understanding real events, and made political involvement in the explosion seem feasible, and thus the subject of public discussion (Doffek 2016).

The spread of different conspiracy theories is also closely related to the appearance of UGC. Such ideas, based on sociological, psychological, humanethological and anthropological grounds, are applied to a public standpoint, supposing that events that are partially or totally undisclosed, or which appear unprovoked - for instance, the explosion in Budapest - are created by 'hidden' actors. However, the phenomenon also occurs when illogical arguments based on evidence are not fully coherent, suggesting to some the existence of a great conspiracy with far-reaching social and political consequences (Ramsay 2006). Most such theories are created when official statements about events are delayed or proven to be erroneous, giving rise to the assumption that somebody wants to hide something. Since this approach appears rational to believers, the main characteristic of conspiracies is that they are hard to contradict: believers characteristically see any professional contradictions as reinforcing their "theory" and as attempts to extinguish evidence (Brotherton 2015). 
On one of the most often read fora, with over four hundred comments related to the explosion, three main theories were put forward by users:

1. deliberate explosion for reason of promoting internal policy goals,

2. explosion independent of policy goals,

3. explosion connected to Islamic faith (konteo.blogrepublik.eu 2016).

In the first category, posited perpetrators include the Hungarian government, the political opposition, and a Russian agent, while theories belonging to the second category include interpretations of the event as an accidental explosion, to send a message to the tenants of the house, a mafia issue, a personal message to the police patrol at the location, or a deliberate attack against the police as an institution (konteo.blogrepublik.eu 2016).

Based on a survey from another popular blog, 1.2 percent of readers thought that the explosion had jihadist connections, 2.5 percent thought it involved a foreign secret service, 12.2 percent an organized gang based in Pest, another 12.2 percent a 'lonely madman', 13.4 percent a private drama between officials, and 57 percent a government conspiracy (bl.blog.hu 2016).

There is something obviously common to the explanations; a civic loss of confidence in official sources of information (Hanula 2013). According to sociopsychologist and political scientist Krekó Péter, conspiracy theories have a stress-releasing impact, especially when individuals are faced with a new and unexplainable, negative phenomenon, since identifying a familiar enemy is cognitively easier than encountering incalculable, chaotic reason (Krekó 2014). According to Krekó, primarily nationalist and anti-globalization conspiracy theories are popular in Hungary, and the Budapest explosion case confirms this. From a socio-psychological perspective it does not matter whether a conspiracy theory is true. If a lot of people believe it, it becomes an organizing power in society and shapes reality (Hanula 2013).

Although it was claimed several times that the perpetrator's act was motivated by his hard life and hatred created during his life through interactions with police (borsonline 2016), this supposition is purely hypothetical; his motivation is still not clear at the time of finishing this study. The perpetrator has made a detailed confession, but did not state his motivation (Német 2017). Despite this, most of the diversified interpretations that arose after the explosion were false, thus official organs - irrespective of the truth - were required to disaffirm these claims as they had not been made by a competent professional whose opinion was worth listening to. Among other conclusions, the moral of the situation involving the explosion on the boulevard is that, in 2016, the word of private individuals articulated in mass media had significant communicative power - a realization that crisis communication must actually deal with (Pintér 2016c). 


\section{ROLE OF THE HOLDING STATEMENT}

In a case so difficult to investigate, the Hungarian police cannot be blamed for not providing any information about the identity of the perpetrator or the aim of the explosion in the first few critical hours, but they can be blamed for not addressing residents for an entire day (Pintér 2016c). In such cases, crisis management protocol (Anthonissen 2009) requires the issuance of a holding statement, which signifies that an investigation is under way and that police are professionally handling the situation and will soon provide full information about events (Anthonissen 2009: 71-72). The primary aim is to increase security and pacify residents, positioning the organization at the epicenter of the crisis as a responsible source which is open to interacting with the media and mediating in crisis publicity (Harrington 2016).

Several content and formal requirements are required of an effective holding statement (IAAPA 2012). On the one hand, it can be understood as a brief, simple and objective declaration that summarizes the occurrence and general background of the crisis event, but does not include specific details (Anthonissen 2009: 71-72). The statement presents the planned activities of the organization in the period following the crisis, and defines priority tasks (imagemanagement.in 2012). It portrays a willingness to co-operate and an openness to communicate with interested parties; it also assures media representatives that the organization will continuously supply them with fresh and carefully controlled information, thereby discouraging journalists from contacting less authentic sources. It names the crisis spokesman as the sole representative of the organization and specifies their exact role (imagemanagement.in 2012). The statement is published within the first hour following the crisis situation through all available channels. Accordingly, such fast initial contact is not only a precondition of properly operating communication channels, but through this the organization also gains time to actually investigate the crisis event and collect information that will help reinstate security as soon as possible.

No matter how brief an announcement like this is, it can set limits on inhabitant or media speculation; while promising a time at which facts will be announced, until then it provides a public point of alignment (Pintér 2016c). It can contain a hint of worry, care and sympathy for residents, but it should basically be a response free from emotion, focusing on facts (IAAPA 2012), calming down the target group, and warning them not to believe harmful, false news. In the case under analysis, it would have been reasonable to refute the two fast-spreading suppositions that a jihadist attack had taken place and that the explosion was politically motivated. 


\section{PROFESSIONAL RECOMMENDATIONS: AN APPROACH SENSITIVE TO SECONDARY REALITY}

As the phenomena that occurred in the critical period following the Budapest explosion show, a crisis communicator needs a problem-sensitive approach and to be proactive, by which means they will be capable of recognizing the hazard of the emergence of conspiracy theories and outwitting them from the very beginning. Since a widely spread conspiracy theory - because of its nature - is quasi-impossible to deny, official organs must publish central, official interpretation as quickly as possible. Naturally, a holding statement does not eliminate speculation, but in the present case it could have helped to dampen down supposition and reduce the scope of possible interpretations of the explosion, while on the other hand it could also have provided a public point of alignment for those with an information deficit (Pintér 2017a: 17).

It is a precondition of the success of any first intervention to recognize that there are two realities in each hazardous situation (Fekete - Sándor 1997: 25). In this case, the first, primary reality is the image that the police and other authorities had about the events in their minds, the likely causes and the specific details; while the secondary reality is created from public, partial acceptance of the official messages sent during crisis communication, and information originating from other sources. This secondary reality is not only composed of heterogeneous components, hence it involves synchronic differences in time. The literature calls the distance between the primary and secondary reality the critical field, to be reduced through the holding statement and all other official statements to the minimum (Fenyvesi 2005: 1).

Accordingly, it is not enough for the police to continuously collect information and broadcast their objective interpretations of such, but if they cannot prevent secondary interpretations by use of a well-timed, professionally written holding statement, then it is vital to take the perceptions of the interest-owners and publicity into account. Regardless of the subjectivity of the latter, their power to form and influence reality must not be underestimated (Pintér 2017a: 18).

Obviously, there might also occur complex situations, the management of which can load the organizations involved so heavily that, besides the investigation and reinstatement of security, no resources remain for proactive communication; moreover, as the case of the Budapest explosion shows, the standpoints and operating arguments of the two professions involved management and communications - may be in opposition (Pintér 2017a: 18). In this case, the professional requirements of management dominated the requirements of public relations; it was reasonable for the authorities to withhold 
some information because of the investigation, and to put greater stress on the organizational aspects of loss mitigation than on those of communication.

This study is not written to call to account the authenticity of decisions and possible omissions of the Hungarian police force; it only aims to create a point of reference and suggest a crisis management approach that integrates all elements of communication to prevent similar such cases in the future. It is not claimed that authorities should align their interpretations of a crisis to public reality in every case, or that the efficiency of crisis communication is more important in eliminating a hazardous situation than the proper application of security technology, management, or socio-psychological approaches. The point is that it is not enough to roll out loss mitigation measures and a communication strategy based on primary reality only; the secondary reality of those involved must be kept in mind, even if this only involves mistaken speculation. Naturally, since the critical field is not developed enough, and the effective power of secondary reality interpretations are not so great as to influence significant masses, the head of a crisis management team may feel it unnecessary to publically deal with the interpretation of a crisis, but managing speculations and distortions that occur after events such as the explosion on the boulevard imply that this decision must involve a conscious choice (Pintér 2017a: 18).

\section{BEYOND THE FOCUS OF THE STUDY: THE DEVELOPMENT OF THE CRISIS}

I have focused only on the phenomena that arose within the first twenty-four hours. For completeness, I also briefly summarize the communication of the police beyond the critical period throughout the course of the crisis, and mention the role of policy as well.

The first official communication took place on the day after the explosion; the national police superintendent and the head of the Central Investigating Prosecution Office provided detailed information about the events at a press conference (Joób 2016b). Their statements showed professionalism in content and style. Their determined behavior and presentation of exact facts stood in opposition to the suppositions and can thus be considered a role model of a response in respect of any future communication (Perlaky-Papp 2016).

At the press conference it was claimed that the authorities saw the desire to kill policemen as being the most feasible motivation for the event. In this regard, the choice of words of the police superintendent, and his standing up for his colleagues and calming other members of the institution were important 
elements of his speech. The preparedness of the two spokespeople, the data they disclosed and their rhetoric partially eliminated and partially avoided any speculation, thus compensating for the delay in response to a certain extent. However, they were not able to disaffirm all suggestions, effectively using the format of the event as a two-way interaction (Pintér 2016c). It was also unique that the police published photos of the suspect, with this initiative almost taking almost the same amount of time that the French authorities had used to disclose information about the perpetrators of the Paris terror attack (Thüringer 2016). The authorities announced the opening of a unique 'green number' (for information-gathering purposes) which was complemented by proposed award of ten million HUF for a tip-off leading to an arrest, and an offer of witness protection (Joób 2016d).

Upon thorough examination of the press conference, counter-productive elements still can be identified. The superintendent did not answer a question concerning whether the event was an 'act of terror', but rather said that the force had identified seven potentially feasible scenarios for justifying the crime. It was rather unfortunate to mention these alternatives without further explanation, partly because of the fairytale number of scenarios. This statement may appear to be accurate, yet it does not provide any facts; it only continues to feed the misinformation created by the media and the suppositions widely disseminated through user-generated content (Pintér 2016c). Although the event was preceded by an entire day of preparation and was broadcast on national live media it featured a poor choice of site, a dysfunctional setting of the scene, and technical failures. The outfits of the speakers were also not very appropriate (ORIGO 2016). It was also not a good choice to feature one of the policemen who had been injured asking for help (Joób 2016e), since this did not inevitably bring us closer to understanding the events but raised ethical concerns about the media and enhanced the dramatic effect; however, it did help to confirm the reality of the content of the event (Pintér 2016c).

Three weeks after the press conference, employees of the Terror Prevention Centre arrested the perpetrator (hirado.hu 2016) in a basement, from which they also seized about two kilograms of explosive material (Horváth-Balogh 2016). The suspect is currently being held in detention under suspicion of committing the crime. Based on a psychiatric test, he has been found competent to stand for the alleged crime (Szemán 2016). However, despite the plentiful speculation that his action has been motivated by a hatred for policemen, created during a life of hardship (borsonline 2016), in reality the perpetrator has not yet confessed his motivation (Német 2017).

In the light of our current knowledge it is known that speculation about the explosion was mainly baseless. However, because of its mass uptake and due to 
the lack of a fast official reaction, the former should have been managed by the police as if it included valid interpretations of the crisis. At the time these lines were being written, the wrapping up and solution of the case were drawing to a close (24.hu 2016). Nevertheless, it is worth mentioning that the Hungarian police force are still engaged with the case.

\section{SUMMARY AND FURTHER RESEARCH}

This study examined Hungarian police communication about an explosion in Budapest in 2016, subject to the protocol of the profession of crisis management (Anthonissen 2009). I have emphasized the time that lapsed before the first formal response and the importance of issuing a holding statement, which not only could have prevented the dissemination of misinformation related to the crisis situation, but could also have created a public point of alignment. I have argued that in cases of hard crisis, delays in the disclosure of official statements might create an information deficit and can result in interest-owners turning to other, less authentic sources.

I outlined the most important circumstances of the explosion and briefly described the tools and literature related to the two professional areas. After this, through analyzing blogs and online press, I reviewed the phenomena that occurred in the twenty-four hours following the crisis; I then gave a detailed presentation of how these responses intensified the crisis. A central claim was that successful crisis communication deals with either 1 . the distortions of the media, and 2. the messages of private persons articulated in mass media, or with the statements of competent experts, since such content - through the intermediation of social media - might influence the masses. Communication about the explosion also provides evidence that the speed and quality of first reactions is of definitive importance in terms of how a crisis plays out (Anthonissen 2009).

Besides distortions of media and user-generated content, one constant element in such crises is the appearance of political forces. In this paper I have not provided a detailed analysis of the communication of the Hungarian government and the opposition, but since governing is presently synonymous with permanent political campaigning, I instead recommend those articles (Perlaky-Papp 2016; Pintér 2016c) which discuss this issue in more detail.

As a final thought, it is worth considering how difficult it is to disentangle crisis management from the socio-political, social environment. Explosions have regularly occurred in Budapest since the 1990s (Szabó 2014); thus in the future it 
would be worth carrying out post hoc analyses of the Ferihegyi main road outrage (Fekete 1991), the Aranykéz Street explosion (Pesti Polgár 1998) and the explosion in front of a bank office in the capital (INDEX 2014) in order to compare the related communications with those which occurred in relation to the Teréz körút attack. On the one hand, the present study implies that such cases (especially in the context of the threat of international terror and the migration crisis) can lead to diversified forms of speculation and media representations, and as such, require management methods that significantly vary - and which are often a lot more complex - from those typically recommended. On the other hand, technology may also influence crisis management protocols, since in the age of social media - and the by-passing of the intermediative role of the media - messages from an endangered institute can reach the public almost immediately (Böhm et al. 2017).

This tendency not only strengthens the demand for crisis publicity that should involve the transmission of the most comprehensive information possible within the shortest time, but it also demands an entirely different type of professional preparation, background knowledge and strategic planning than was employed with the crises that occurred in the age of traditional media. Furthermore, thanks to the internet, crises practically never get old, as information about past events is easily available to everyone. Examination of the impact of media convergence on crisis management can inevitably enrich the related methodology, since thanks to social media numerous "new types" of situations are appearing and endangering reputation or data security - a nonexistent phenomenon twenty years ago, in the age of traditional media (Neumann - Pintér 2018).

\section{REFERENCES}

Agnew, Spiro Theodore (1969) "Television News Coverage", American Rhetoric. com, http://www.americanrhetoric.com/speeches/PDFFiles/Spiro\%20 Agnew\%20-\%20TV\%20News\%20Coverage.pdf Accessed: 30 May 2017 An, Seon-Kyoung - Ing-Haw Cheng (2010), "Crisis Communication Research in Public Relations Journals: Tracking Research Trends Over Thirty Years", in: Coombs, W. Timothy, Holladay, Sherry J., eds., The Handbook of Crisis Communication, Oxford, UK., Wiley-Blackwell, pp. 65-89. http://dx.doi. org/10.1002/9781444314885.ch3

Anthonissen, Peter Frans (2009), Crisis Communication, Kogan Page Publishers Bajomi-Lázár, Péter (2009), "Hírközlés tegnap és ma", Médiakutató, http://www. mediakutato.hu/cikk/2009_03_osz/10_hirkozles (Broadcasting yesterday and today) Accessed: 30 May 2017 
Beniger, James R. (1986), The Control Revolution: Technological and Economic Origins of the Information Society. Cambridge, Mass., Harvard University Press Bőhm, Kornél - Pintér Dániel Gergő - Petrányi-Széll András - Horváth Mónika - Sztaniszláv András (2017), "Annual Crisis Report of Hungary”, Hungarian Public Relations Association, pp. 8-9.

Brotherton, Rob (2015), Suspicious Minds - Why We Believe Conspiracy Theories, Bloomsbury, Sigma

Bundy, Jonathan - Michael D. Pfarrer - Cole E. Short - W. Timothy Coombs (2016), "Crises and crisis management: Integration, interpretation, and research development", Journal of Management, Vol. 43, Issue 6, pp. 1661 1692 http://dx.doi.org/10.1177/0149206316680030

Castells, M. (2006), The Network Society: from Knowledge to Policy. in: M. Castells \& G. Cardoso (Eds.): The Network Society: From Knowledge to Policy, The Johns Hopkins University Press, Center for Transatlantic Research Relations, Washington, DC. pp. 3-22.

Coombs, W. Timothy (2007), "Protecting organization reputations during a crisis: The development and application of situational crisis communication theory", Corporate Reputation Review, Vol. 10, No 3, pp. 163-176. http:// dx.doi.org/10.1057/palgrave.crr.1550049

Coombs, W. Timothy (2010a), "Parameters for Crisis Communication", in: Coombs, W. Timothy - Sherry J. Holladay, eds., The Handbook of Crisis Communication, Wiley-Blackwell, Oxford, UK, pp. 17-53. http://dx.doi. org/10.1002/9781444314885.ch1

Coombs, W. Timothy (2010b), "Crisis communication: A developing field", in: Heath R. L. ed., The Sage handbook of public relations, Thousand Oaks, CA: Sage, pp. 477-488.

Fekete, Ferenc - Sándor Imre (1997), Válságkezelés és Kríziskommunikáció (Crisis communication and crisis management) Budapest, Budapesti Közgazdasági Egyetem, p. 25.

Fenyvesi, Éva (2005), "A hatékony válságkommunikáció", Vezetéstudomány. Vol. 38, No 1, pp. 23-28. http://avf.hu/tanarok/fenyvesi-eva/?download=ahatekonyva lsagkommunikacio.pdf(Effective crisis communication) Accessed: 30 May 2017 Glynn, Kevin (2000), Tabloid Culture: Trash Taste, Popular Power, and the Transformation of American Television, Duke University Press

Gregory Bateson (1979), Mind and Nature: A Necessary Unity, E. P. Dutton, New York, https://monoskop.org/images/c/c3/Bateson_Gregory_Mind_and_ Nature.pdf Accessed: 30 May 2017

Groh, Maximilian (2014), "Strategic Management in Times of Crisis", American Journal of Economics and Business Administration, Vol. 6, No 2, pp. 49-57. http://dx.doi.org/10.3844/ajebasp.2014.49.57 
Harrington, Katie (2016), "Crisis Communications: Preparing your holding statement", http://wildewords.ie/crisis-communications-holding-statements/ Accessed: 30 May 2017

iaapa.org (2012), “IAAPA's Quick Guide: Crisis Communications", http://www. iaapa.org/docs/default-document-library/crisis-communications-(english). pdf?sfvrsn=0 Accessed: 30 May 2017

imagemanagement.in (2012), "Crisis Management - 6 Tips for Writing a Holding Statement", http://imagemanagement.in/2012/10/04/crisis-management-6tips-for-writing-a-holding-statement/ Accessed: 30 May 2017

Jacobson, Sandra W. (1979), "Matching behavior in the young infant", Child Development, Vol. 50, No 2. pp. 425-430. http://dx.doi.org/10.2307/1129418 Jacques, Jean-Marie - Laurent Gatot - Anne M. Wallemacq (2007), "A cognitive approach to crisis management in organizations" in: Pearson, Christine M. Christophe Roux-Dufort C., Judith A. Clair, eds., International handbook of organizational crisis management, Thousand Oaks, CA, Sage, pp. 161-193. http://dx.doi.org/10.4135/9781412982757.n6

Kahn, William A. - Michelle A. Barton - Steven Fellows (2013), “Organizational crises and the disturbance of relational systems", Academy of Management Review, Vol. 38, No 3, pp. 377-396. http://dx.doi.org/10.5465/amr.2011.0363

Krekó, Péter (2014), “Összeesküvés-elmélet, mint kollektív motivált megismerés", ELTE, http://www.ppk.elte.hu/file/KrekoPeter_dissz.pdf (Conspiracy theory as collective motivated cognition) Accessed: 30 May 2017 McQuail, Denis (2010), McQuail's Mass Communication Theory, 6th ed. London, Sage

Neumann, Peter - Pintér, Dániel Gergő (2018), “Technology-based critical phenomena: a Borgmannianapproach of crisis prediction", BUDPT2017 Conference Book.

Nyárádi, Gáborné - Szeles Péter (1999), Public Relations II. Perfekt Kiadó. Budapest, pp. 116, 284-289.

Pavlik, John (2014), Converging Media, New York, New York, Oxford University Press

Perlaky-Papp, József (2016), "A körúti robbantás kríziskommunikációjáról", http://kozbeszelo.blog.hu/2016/09/26/a_koruti_robbantas krizsikommunikaciojarol?utm_source=bloghu_megosztas\&utm medium=facebook_share\&utm_campaign=blhshare (About the crisis communication of the explosion on the boulevard) Accessed: 30 May 2017

Pintér, Dániel Gergő (2016a), "Public Self-Demolition in Practice: The Conclusions of the Crisis Communication of the Children Cancer Foundation from the Perspective of Public Relations", Periodica Polytechnica Social and Management Sciences, Vol. 24, No 1, pp. 41-51. http://dx.doi.org/10.3311/PPso.8472 
Pintér, Dániel Gergő (2016b), “A vállalat felelősségvállalásától az érdekgazdák észleléséig: a Szituációs Kríziskommunikációs Elmélet és a Kommunikációs Keretezés Elmélet kapcsolódási pontjainak feltárása a válságkommunikáció módszertanának fejlesztése céljából" (From the undertaking liability of the company to the cognition of the stakeholders: exploration of the junction points between the Situational Crisis Communication Theory and the Communication Framing Theory in order to develop the methodology of crisis communication), JelKép 2016, No 3, pp. 34-52. http://dx.doi.org/10.20520/ JEL-KEP.2016.3.35

Pintér, Dániel Gergő (2016c), “A körúti bumm, avagy a konteóhívők aranyborjúja", Kreativ, http://www.kreativ.hu/cikk/a_koruti_bumm avagy_a_konteohivok_aranyborjuja (The boulevard boom or the golden calf of contheos) Accessed: 30 May 2017

Pintér, Dániel Gergő (2016d), "Various challenges of science communication in teaching generation $\mathrm{Z}$ : an urgent need for paradigm shift and embracing digital learning", Opus et Educatio Vol. 3, No 6, pp. 674-698. http://opuseteducatio. hu/index.php/opusHU/article/view/146/189 Accessed: 30 May 2017

Pintér, Dániel Gergő (2017a), “A rendőrség kommunikációja a 2016os budapesti robbantás kapcsán: az átmeneti nyilatkozat jelentősége a krízismenedzsmentben" (The Communication of the Hungarian Police Forces about 2016 Budapest Bombing: the Role of the First Official Reaction in Crisis), Információs Társadalom Vol. 16, No 4, pp. 6-25. http://dx.doi.org/10.22503/ inftars.XVI.2016.4.1

Ramsay, Robin (2006), Conspiracy Theories, Oldcastle Books

Roux-Dufort C. (2007), "Is crisis management (only) a management of exceptions?", Journal of Contingencies and Crisis Management Vol. 15, No 2, pp. 105-114. http://www.projectwhitehorse.com/pdfs/Crisis\%20Mgmt $\% 20$ Only\%20Mgmt\%20of\%20Exceptions\%20-\%20Roux-Dufort.pdf Accessed: 30 May 2017

Seeger, Matthew W. - Timothy L. Sellnow - Robert R. Ulmer (1988), "Communication, organization, and crisis", in: Michael E. Roloff ed., Communication Yearbook Vol. 21, No 1, Thousand Oaks, SA, Sage, pp. 231-275. Tanács, János - Zemplén Gábor (2015), "Válság, kommunikáció, érvelés: Kríziskommunikáció argumentáció-elméleti nézőpontból”, JelKép 2015, No 2, pp. 1-14. http://communicatio.hu/jelkep/2015/2/JelKep_2015_2_ Tanacs_Janos_Zemplen_Gabor.pdf (Crisis communication, argument: Crisis communication from the viewpoint of argumentation theory) Accessed: 30 May 2017

Venette, Steven James (2003), "Risk communication in a High Reliability Organization: APHIS PPQ's inclusion of risk in decision making”, $A$ 
Dissertation Submitted to the Graduate Facultyof the North Dakota State University of Agriculture and Applied Science, Fargo, North Dacota, p. 43. https://www.researchgate.net/publication/35945622_Risk_communication in_a_high_reliability_organization_APHIS_PPQ's_inclusion_of_risk_in_ decision_making Accessed: 30 May 2017

Zelizer, Barbie (2009), The Changing Faces of Journalism: Tabloidization, Technology and Truthiness, London and New York, Routledge

\section{ANALYSED ONLINE SOURCES}

atv.hu (2016), "A DK attól tart, hogy a Fidesz terrortámadásokat fog megrendelni”, http:/www.atv.hu/belfold/20160923-a-dk-attol-tart-hogya-fidesz-terrortamadasokat-fog-megrendelni (DK is afraid that Fidesz will order terror attacks) Accessed: 30 May 2017

24.hu (2016), "Hiába próbálkozott, rács mögött marad a Teréz körúti robbantó", http://24.hu/belfold/2016/11/21/hiaba-probalkozott-racs-mogott-marad-aterez-koruti-robbanto/ (No matter how he tried, the Teréz körút detonator will stay behind bars) Accessed: 30 May 2017

bl.blog.hu (2016), "Miért robbantottak a körúton? - az összes konteó + szavazás", http://b1.blog.hu/2016/09/28/miertbumm (What was the boulevard explosion due to? - all of the conspiracy theories + voting) Accessed: 30 May 2017

borsonline.hu (2016), "Kamaszkora óta gyülölheti a rendöröket a Teréz körúti robbantó", http://www.borsonline.hu/aktualis/kamaszkora-ota-gyulolheti-arendoroket-a-terez-koruti-robbanto/121017 (The Teréz körút detonator might have hated policemen since his childhood) Accessed: 30 May 2017

Dull, Szabolcs (2016) "Elfogták a teréz körúti robbantás gyanúsítottját”, http:// index.hu/belfold/2016/10/19/terez_koruti_robbantas_a_tek-esek_elfogtak_ egy_ferfit/ (Suspected perpetrators of the Teréz körút detention are arrested) Accessed: 30 May 2017

Fekete, Gy. Attila (1991) "A terrorista német útlevéllel érkezett" (The terrorist arrived with a German passport) Népszabadság, p. 4.

Gábor, Doffek (2016), "Sehogy sem stimmel a körúti robbantás", http:// frontembermegmondja.blogspot.hu/2016/09/sehogy-sem-stimmel-korutirobbantas.html (Nothing fits around the explosion on the boulevard) Accessed: 30 May 2017

Hanula, Zsolt (2013), "Ezért van szükségünk zsidó gyíkemberekre”, http://index. hu/tudomany/2013/11/21/ezert_van_szuksegunk_zsido_gyikemberekre/ (This is why we need Jewish lizard-men) Accessed: 30 May 2017 
hirado.hu (2016), "Karmacson foghatták el a Teréz körúti robbantás feltételezett tettesét", http://www.hirado.hu/2016/10/19/elfogtak-a-terez-koruti-robbantot/ (The suspected perpetrator of the Teréz körút explosion was arrested in Karmacs) Accessed: 30 May 2017

Horváth-Balogh, Attila (2016), "A TEK ellepte a falut - Homokkomáromban lakott a Teréz körúti robbantó", http://zaol.hu/hirek/a-tek-ellepte-a-faluthomokkomaromban-lakott-a-terez-koruti-robbanto-1797173 (TEK occupied the village - the Teréz körút detonator lived in Homokkomárom) Accessed: 30 May 2017

hvg.hu (2016), “Rendőrök sérültek meg a Teréz körúti robbanásban fejlemények", http://hvg.hu/itthon/20160924_Robbanas_a_Terez_koruton_ serultek_is_vannak (Policemen were injured in the Teréz körút explosion developments) Accessed: 30 May 2017

INDEX (2014), "Robbantás egy pesti bankfiók előtt", http://index.hu/ belfold/2014/01/13/robbanas_egy_pesti_bankfiokban/ (Explosion in front of a bank office in Pest) Accessed: 30 May 2017

Joób, Sándor - Dull Szabolcs - Munk Veronika (2016), "12 fontos kérdés a körúti robbantásról", http://index.hu/belfold/2016/09/26/robbantas_mit_lehet_tudni/ (12 important questions about the explosion on the boulevard) Accessed: 30 May 2017

Joób, Sándor (2016a), "Házi készítésü bomba robbant éjjel a Körúton, a rendöröket ki akarták végezni”, http://index.hu/belfold/2016/09/25/terez_ koruti_robbanas_rendorseg_orfk_kozponti_nyomozo_fougyeszseg/ (Homemade bomb exploded on the Boulevard at night - they wanted to execute the policemen) Accessed: 30 May 2017

Joób, Sándor (2016b), "Ki akarták végezni a rendőröket", http://index.hu/ belfold/2016/09/25/ki_akartak_vegezni_a_rendoroket/ (They wanted to execute the policemen) Accessed: 30 May 2017

Joób, Sándor (2016c), "Furcsa dolgokat látott a robbantásnál a két rendör mögött sétáló szemtanú", http://index.hu/belfold/2016/09/26/furcsa_dolgokat_ latott_a_robbantasnal_a_ket_rendor_mogott_setalo_szemtanu/ (The eyewitness walking behind the two policemen saw strange things) Accessed: 30 May 2017

Joób, Sándor (2016d), "Ki kaphatja meg a nettó tízmillió forintos nyomravezetői díjat?", http://index.hu/belfold/2016/09/25/ki_kaphatja_meg_a_netto_10_ millios_nyomravezetoi_dijat (Who can get the net HUF 10 million reward?) Accessed: 30 May 2017

Joób, Sándor (2016e), “Itt hallgathatja meg a robbantásban megsérült rendőr segélykérését", http://index.hu/belfold/2016/09/25/itt_hallgathatja_ meg_a_robbantasban_megserult_rendor_segelykereset/ (The policemen 
injured in the explosion asking for help can be listened to here) Accessed: 30 May 2017

konteo.blogrepublik.eu (2016), “Villámkonteó: robbantás a nagykőrúton”, http:// konteo.blogrepublik.eu/2016/09/25/villamkonteo-robbantas-a-nagykoruton/ (Thunder-contheo: explosion on the grand boulevard) Accessed: 30 May 2017 Mészáros, Tamás (2016), "Az emberek több mint fele elmenne, mégsem lenne érvényes a kvótanépszavazás", http://index.hu/belfold/2016/09/24/ az_emberek_tobb_mint_fele_elmenne_megsem_lenne_ervenyes_a kvotanepszavazas/ (If more than half of the people participate the referendum will be valid) Accessed: 30 May 2017

Német, Tamás (2017), “A Teréz körúti robbantó állítja, nem ismerte a rendöröket”, http://index.hu/belfold/2017/02/21/a_terez_koruti_robbanto_allitja_nem_ ismerte_a_rendoroket/ (The Teréz körút detonator states that he did not know the policemen) Accessed: 30 May 2017

ORIGO (2016), "Rendőrfőkkapitány: A rendőreimet ki akarták végezni”, http:// www.origo.hu/itthon/20160925-robbanas-fovaros-rendorseg-csobombakozponti-nyomozo-fougyeszseg.html (Police superintendent: they wanted to execute my policemen) Accessed: 30 May 2017

Pesti Polgár (1998), "Tragédia az Aranykéz utcában", http://www.pestipolgar. tvnet.hu/980301.html (Tragedy in the Aranykéz utca) Accessed: 30 May 2017 Privátbankár (2016), "Robbanás rázta meg Budapestet-lezárták a Nagykörutat", http://privatbankar.hu/kozerdeku/robbanas-razta-meg-budapestet-lezartak-anagykorutat-298516 (Explosion rocked Budapest - the Nagy körút was closed down) Accessed: 30 May 2017

Szabó, Dániel (2014), “Kis magyar robbantás történelem”, http://vs.hu/kozelet/ osszes/kis-magyar-robbantas-tortenelem-0113\#!s0 (Brief history of the Hungarian explosion) Accessed: 30 May 2017

Szemán, László János (2016), "Büntethető a vélt robbantó", http://magyaridok. $\mathrm{hu} /$ belfold/buntetheto-velt-robbanto-1261213/ (The alleged detonator is punishable) Accessed: 30 May 2017

Thüringer, Barbara (2016), "Kiadta a rendőrség a körúti robbantásról készült videofelvételt", http://index.hu/belfold/2016/09/26/robbantas_rendorseg_ video/ (The police disclosed the records taken about the explosion on the boulevard) Accessed: 30 May 2017

valasztas.hu (2016), "A Nemzeti Választási Bizottság150/2016. számú határozata", http://www.valasztas.hu/hu/nvb/hatarozatok/2016/2016-5867. html (No 150/2016 Resolution of the National Committee of Voting) Accessed: 30 May 2017 
